\title{
Dialysis with high-flux membranes significantly affects plasma levels of neutrophil gelatinase-associated lipocalin
}

\author{
Carlo Donadio \\ See related research by Schilder et al. http://www.ccforum.com/content/18/2/R78, \\ and related correspondence by Honore et al., http://www.ccforum.com/content/19/1/392.
}

I read with interest the recent article by Schilder et al. reporting that plasma levels and the biomarker value of neutrophil gelatinase-associated lipocalin (NGAL) in critically ill patients with acute kidney injury (AKI) are not affected by continuous venovenous hemofiltration (CVVH) [1]. Recently, Honore et al. [2] commented on the data by Schilder et al., suggesting that further studies are warranted to definitely assess the membranes and the dialytic techniques that can remove NGAL from plasma and thus affect its accuracy as a marker of AKI.

Our results in 31 patients on maintenance hemodialysis (MHD), published in Critical Care as part of a study that evaluated the effect of glomerular filtration rate impairment on diagnostic performance of NGAL [3], appear quite different from those found by Schilder et al. in critically ill patients who received CVVH. Patients on MHD received low-flux dialysis (23 treatments) with a polysulfone membrane (F8; Fresenius, Bad Homburg, Germany), or different high-flux membranes. High-flux dialysis treatments were performed in 13 patients by using a triacetate cellulose membrane with a surface of $1.9 \mathrm{~m}^{2}$ and an ultrafiltration rate (UFR) of $8474 \mathrm{~mL} / \mathrm{h}$ per 100 mm Hg (N190 FH; Nipro, Osaka, Japan). The remaining eight treatments were performed as hemodiafiltration with a polyphenylene membrane with a surface of $2.0 \mathrm{~m}^{2}$ and a UFR of $6800 \mathrm{~mL} / \mathrm{h}$ per $100 \mathrm{~mm}$ $\mathrm{Hg}$ (Phylther; Bellco, Mirandola, Italy) or as an acrylonitril and natrium metallylsulfone copolymer membrane with a surface of $2.15 \mathrm{~m}^{2}$ and a UFR of $6500 \mathrm{~mL} / \mathrm{h}$ per $100 \mathrm{~mm}$ $\mathrm{Hg}$ (Nephral 500; Gambro, Lund, Sweden). Dialysis length was $4.0 \pm 0.2 \mathrm{~h}$, and blood flow was $312 \pm 43 \mathrm{~mL} / \mathrm{min}$. Mean plasma concentrations of NGAL increased by $9.1 \pm 24.4 \%$ at the end of low-flux dialysis, indicating that low-flux polysulfone did not remove NGAL (Fig. 1). Treatments with high-flux membranes decreased plasma NGAL significantly $(P<0.0001)$. The reduction ratio of NGAL was higher after hemodiafiltration $(52.1 \pm 26.7 \%)$ than after high-flux dialysis $(26.6 \pm 26.1 \%, P=0.053)$.

Schilder et al. performed CVVH treatments with a triacetate membrane with a surface of $1.9 \mathrm{~m}^{2}$ (UF-205), a UFR of $3700 \mathrm{~mL} / \mathrm{h}$ per $100 \mathrm{~mm} \mathrm{Hg}$ lower than that of our triacetate membrane, and a lower sieving coefficient for middle molecules ( 0.81 versus 0.91 for myoglobin). During treatments, the blood flow was kept at $180 \mathrm{~mL} / \mathrm{min}$ and the substitution fluid at $2 \mathrm{~L} / \mathrm{h}$. These differences can justify, at least in part, the lower removal of NGAL found in patients with AKI than in patients on MHD.

Besides the chemical composition of the membrane, different parameters of the dialysis session may influence the removal of NGAL. Therefore, further studies are warranted to assess the membranes and the dialytic techniques that can affect the accuracy of NGAL as a marker of AKI.

Correspondence: carlo.donadio@med.unipi.it

Department of Clinical and Experimental Medicine, Division of Nephrology, University of Pisa, Via Savi 10, 56100 Pisa, Italy 


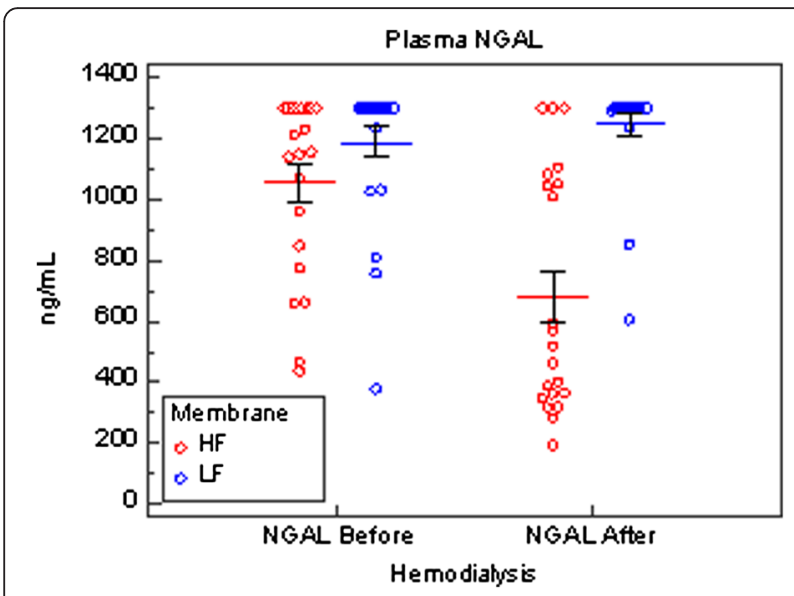

Fig. 1 Effect of dialysis with low-flux (LF) or high-flux (HF) membranes on plasma concentrations of neutrophil gelatinase-associated lipocalin (NGAL) in 31 patients on maintenance hemodialysis

\section{Abbreviations}

AKI: Acute kidney injury; CWH: Continuous venovenous hemofiltration; MHD: Maintenance hemodialysis; NGAL: Neutrophil gelatinase-associated lipocalin; UFR: Ultrafiltration rate.

\section{Competing interests}

The author declares that he has no competing interests.

Published online: 31 January 2016

\section{References}

1. Schilder L, Nurmohamed SA, ter Wee PM, Paauw NJ, Girbes AR, Beishuizen A, et al. The plasma level and biomarker value of neutrophil gelatinase-associated lipocalin in critically ill patients with acute kidney injury are not affected by continuous venovenous hemofiltration and anticoagulation applied. Crit Care. 2014;18:R78.

2. Honore PM, Jacobs R, Hendrickx I, De Waele E, Van Gorp V, Spapen HD. Is neutrophil gelatinase-associated lipocalin unaffected by convective continuous renal replacement therapy? Definitely... maybe. Crit Care. 2015;19:392.

3. Donadio C. Effect of glomerular filtration rate impairment on diagnostic performance of neutrophil gelatinase-associated lipocalin and B-type natriuretic peptide as markers of acute cardiac and renal failure in chronic kidney disease patients. Crit Care. 2014;18:R39.

\section{Submit your next manuscript to BioMed Central and take full advantage of:}

- Convenient online submission

- Thorough peer review

- No space constraints or color figure charges

- Immediate publication on acceptance

- Inclusion in PubMed, CAS, Scopus and Google Scholar

- Research which is freely available for redistribution

Submit your manuscript at www.biomedcentral.com/submit 